\title{
Kompetensi Penyuluh Tenaga Harian Lepas Tenaga Bantu Penyuluh Pertanian di Kabupaten Garut, Jawa Barat
}

\section{Competence of Agricultural Extension Assistant Worker in Garut, West Java}

\author{
Herry Pramono ${ }^{1}$, Anna Fatchiya ${ }^{2}$, Dwi Sadono ${ }^{2}$ \\ ${ }^{1}$ Inspektorat Jenderal Kementerian Pertanian \\ ${ }^{2}$ Departemen Sains Komunikasi dan Pengembangan Masyarakat Fakultas Ekologi Manusia, Institut Pertanian Bogor
}

\begin{abstract}
The government has set a target of a sustainable self-sufficiency in rice, corn and soybean to be achieved by 2018. The agricultural extension activity is an effort in achieving these targets. One of the constraints in agricultural extension activities is the limited number of agricultural extension workers, so the government recruits assistant workers. The competence of an extension worker is needed to carry out activities based on the knowledge and skills. This study was aieds to measure the competence of agricultural extension assistant workers and analyze the factors that influence it. This study used a survey method and was carried out in Garut, West Java. Data was collected using a census from 119 agricultural extension assistant workers. Generally, the competence of the agricultural extension assistants is in the low category (57,80\%), with the average competency score of 32.49. The resulted analysis using a regression model found that the understanding of the farmer's needs was affected by motivation, and an effective communication influenced by the amount of training, the number of villages and motivation. Overall, the competence of agricultural extension assistants is influenced by the number of farmer groups, the number of village and motivation.
\end{abstract}

Keywords: agricultural extension assistant worker, competence, farmer groups, motivation

\begin{abstract}
Abstrak
Pemerintah telah menetapkan target swasembada berkelanjutan padi, jagung dan kedelai yang harus dicapai pada tahun 2018 . Kegiatan penyuluhan pertanian merupakan salah satu upaya untuk mencapai target tersebut. Salah satu kendala dalam kegiatan penyuluhan pertanian adalah jumlah tenaga penyuluh pertanian yang masih sangat kurang sehingga pemerintah merekrut penyuluh Tenaga Harian Lepas Tenaga Bantu Penyuluh Pertanian (THL TBPP). Kompetensi penyuluh sangat dibutuhkan untuk melaksanakan kegiatan penyuluhan karena merupakan kemampuan untuk melaksanakan kegiatan yang dilandasi pengetahuan dan keterampilan. Penelitian ini bertujuan untuk mengukur tingkat kompetensi penyuluh THL TBPP dan menganalisis faktorfaktor yang mempengaruhinya. Penelitian ini menggunakan metode survei yang dilakukan di Kabupaten Garut Provinsi Jawa Barat. Data dikumpulkan secara sensus pada 119 penyuluh THL TBPP. Secara umum, kompetensi penyuluh THL TBPP berada dalam kategori rendah $(57,80 \%)$ memiliki nilai kompetensi rata-rata 32,49. Hasil analisis menggunakan model regresi menemukan bahwa pemahaman kebutuhan petani dipengaruhi oleh motivasi, pemahaman komunikasi yang efektif dipengaruhi oleh jumlah pelatihan, jumlah desa dan motivasi. Secara keseluruhan kompetensi penyuluh THL TBPP dipengaruhi oleh faktor jumlah kelompok tani binaan, jumlah desa binaan dan motivasi.
\end{abstract}

Kata kunci: penyuluh THL TBPP, kompetensi, kelompok tani, motivasi

\section{Pendahuluan}

Pemerintah masih menghadapi berbagai kendala dalam upaya pemenuhan kebutuhan pangan masyarakat, diantaranya jumlah penduduk yang terus meningkat, kerusakan lingkungan dan perubahan iklim, terbatasnya infrastruktur (jaringan irigasi, jalan usahatani), belum cukup tersedianya benih unggul bermutu, pupuk, pakan, pestisida/obat-obatan, alat dan mesin pertanian hingga ke tingkat usahatani, konversi lahan pertanian produktif ke penggunaan nonpertanian yang tidak terkendali dan ketergantungan konsumsi beras. Di tengah kondisi tersebut, pemerintah menetapkan target swasembada berkelanjutan padi dan jagung serta swasembada kedelai yang harus dicapai pada tahun 2018 (Kementan, 2015). Berbagai upaya telah dilaksanakan untuk mencapai target tersebut, antara lain melalui fasilitasi sarana produksi pertanian dan kegiatan penyuluhan pertanian.

Salah satu kendala dalam pelaksanaan penyuluhan pertanian adalah kurangnya jumlah tenaga penyuluh. Hal tersebut mengakibatkan beban kerja setiap penyuluh cukup besar karena wilayah binaan penyuluh cukup luas dan jumlah kelompok tani binaan 
cukup banyak. Pada tahun 2016, jumlah penyuluh pertanian di seluruh Indonesia sebanyak 47.898 orang terdiri dari PNS 25.932 orang $(54,14 \%)$, penyuluh THL APBN 19.083 orang $(39,84 \%)$ dan penyuluh THL APBD 2.883 orang $(6,02 \%)$ sedangkan jumlah desa/kelurahan di seluruh Indonesia sebanyak 78.063 sehingga untuk memenuhi kebutuhan satu desa satu penyuluh masih terdapat kekurangan tenaga penyuluh pertanian sebanyak 30.165 orang (Pusluhtan, 2016). Pada lima hingga sepuluh tahun ke depan diperkirakan jumlah penyuluh pertanian akan berkurang banyak karena pensiun.

Pemerintah telah berupaya mengatasi kekurangan jumlah penyuluh pertanian dengan merekrut penyuluh THL APBN/Tenaga Harian Lepas Tenaga Bantu Penyuluh Pertanian (THL TBPP). Penyuluh THL TBPP direkrut oleh pemerintah pada tahun 2007 hingga 2009 untuk membantu penyuluh pertanian PNS melaksanakan kegiatan penyuluhan pertanian. Penyuluh THL TBPP direkrut selama kurun waktu tertentu untuk melaksanakan tugas dan fungsinya serta tidak menuntut untuk diangkat menjadi Pengawai Negeri Sipil (PNS). Sebenarnya tugas penyuluh THL TBPP hanya sebatas membantu penyuluh pertanian PNS, namun karena jumlah penyuluh pertanian PNS yang sangat kurang, maka banyak penyuluh THL TBPP yang harus melaksanakan tugas penuh sebagai penyuluh pertanian (Paay, 2012).

Penyuluh THL TBPP masih dihadapkan pada beberapa keterbatasan diantaranya tingkat pendidikan yang masih rendah (sebagian besar SMK), jumlah pelatihan yang masih kurang, honor yang sangat kecil dan fasilitas untuk melaksanakan kegiatan penyuluhan pertanian yang sangat terbatas. Dengan segala keterbatasan tersebut, penyuluh THL TBPP dituntut untuk melaksanakan tugas yang sama dengan penyuluh pertanian PNS. Selain itu kurangnya jumlah tenaga penyuluh pertanian menambah beban bagi penyuluh THL TBPP karena wilayah binaan cukup luas dan jumlah kelompok tani binaan cukup banyak (Sapar, 2011; Hernanda, 2015).

Kabupaten Garut memiliki jumlah penyuluh THL TBPP sebanyak 119 orang yang merupakan terbanyak keempat di Jawa Barat setelah Kabupaten Kuningan, Cirebon dan Tasikmalaya. Kabupaten Garut memiliki potensi yang cukup besar dalam pengembangan pertanian, memiliki luas lahan pertanian 171.831 ha dengan komoditas pertanian unggulan padi dan jagung (BP4K Kabupaten Garut, 2016). Pada tahun 2014 produktivitas tanaman jagung sebesar 7,9 ton/ha yang merupakan produktivitas tertinggi urutan pertama, produktivitas tanaman padi sebesar $6,1 \mathrm{ton} /$ ha yang merupakan produktivitas tertinggi ketujuh dan produktivitas tanaman kedelai sebesar 1,5 ton/ ha yang merupakan produktivitas tertinggi ke 15 di Jawa Barat (BPS Jawa Barat, 2015). Pada tahun 2015 produktivitas tanaman jagung sebesar 8,3 ton/ha yang merupakan produktivitas tertinggi urutan pertama, produktivitas tanaman padi sebesar 6,2 ton/ha yang merupakan produktivitas tertinggi urutan keenam, produktivitas tanaman kedelai sebesar 1,6 ton/ha yang yang merupakan produktivitas tertinggi urutan ke sebelas di Jawa Barat (BPS Kabupaten Garut, 2016). Produktivitas tanaman jagung, padi dan kedelai mengalami peningkatan pada tahun 2015 dibandingkan tahun 2014, namun demikian produktivitas tanaman padi dan kedelai masih rendah dibandingkan dengan beberapa kabupaten lainnya.

Kondisi petani pada saat ini menunjukkan adanya peningkatan wawasan, pengetahuan, keterampilan, kemampuan dan sikap kritis terhadap pembangunan pertanian. Hal ini ditunjukkan dengan tuntutan petani terhadap pelayanan penyuluhan yang bermutu sesuai kebutuhannya. Kondisi ini tentunya memerlukan adanya penyuluh pertanian yang memiliki kompetensi di bidangnya yakni memiliki kemampuan untuk melaksanakan tugas yang didasari dengan pengetahuan dan keterampilan.

Kompetensi mempunyai arti sebagai kemampuan seseorang yang dapat terobservasi, serta mencakup atas pengetahuan, keterampilan dan sikap kerja seseorang dalam menyelesaikan suatu fungsi dan tugas atau pekerjaan sesuai dengan persyaratan pekerjaan yang ditetapkan (Kemennakertrans, 2010). Stone (Brodeur et al., 2011) mendefinisikan kompetensi sebagai penerapan pengetahuan, keterampilan teknis, dan karakteristik pribadi yang menghasilkan kinerja yang luar biasa yang harus digunakan sebagai landasan untuk meningkatkan kinerja profesional penyuluh. Sumardjo (2010) menyebutkan bahwa kompetensi yang dimiliki penyuluh setidaknya terdiri dari empat hal.

Pertama, kompetensi personal yaitu kesesuaian sifat bawaan dan kepribadian penyuluh yang tercermin dari kemampuan membawakan diri, kepemimpinan, kesantunan, motif berprestasi, kepedulian, disiplin, terpercaya, tanggung-jawab, dan ciri kepribadian penyuluh lainnya. Kedua, kompetensi sosial 
menyangkut kemampuan-kemampuan berinteraksi/ berhubungan sosial, melayani, bermitra, bekerjasama dan bersinergi, mengembangkan kesetiakawanan, kohesif, dan mampu saling percaya mempercayai. Ketiga, kompetensi andragogik menyangkut kemampuan metodik dan teknik pembelajaran/ mengembangkan pengalaman belajar untuk mempengaruhi dan merubah pengetahuan/wawasan, ketrampilan/tindakan dan sikap (minat) sasaran penyuluhan, membangkitkan kebutuhan belajar/ berubah, menyadari tanggung jawab dan kebutuhan sasaran penyuluhan. Keempat, kompetensi komunikasi inovatif menyangkut reaktualisasi diri, penguasaan teknologi informasi, kemampuan berempati, kemampuan komunikasi partisipatif/konvergensi, menggali dan mengembangkan pembaharuan, serta kewiraswastaan (entrepreneurship).

Berkaitan dengan penyelenggaraan penyuluhan pertanian, Sumardjo (Nuryanto, 2008) mengemukakan bahwa ada delapan kompetensi yang diperlukan oleh penyuluh untuk dapat mendukung pelaksanaan pekerjaannya yaitu: (1) kemampuan berkomunikasi secara konvergen dan efektif, (2) kemampuan bersinergi kerjasama dalam tim, (3) kemampuan akses informasi dan penguasaan inovasi, (4) sikap kritis terhadap kebutuhan atau keterampilan analisis masalah, (5) keinovatifan atau penguasaan teknologi informasi dan disain komunikasi multi media, (6) berwawasan luas dan membangun jejaring kerja, (7) pemahaman potensi wilayah dan kebutuhan petani, dan (8) keterampilan berpikir logis (berpikir sistem).

Kompetensi diduga dipengaruhi oleh beberapa faktor diantaranya karakteristik individu, motivasi dan persepsi. Robbins (1996) mengungkapkan karakteristik individu akan menjadikan seseorang berperilaku positif yang berarti disiplin dan sebaliknya jika tidak sesuai cenderung berperilaku tidak disiplin. Mardikanto (2009) menyatakan beberapa karakteristik diantaranya karakteristik pribadi, mencakup jenis kelamin, umur, suku/etnis, agama dan karakteristik status sosial ekonomi, meliputi tingkat pendidikan, tingkat pendapatan dan keterlibatan dalam kelompok/ organisasi kemasyarakatan.

Motivasi adalah tindakan atau aktivitas oleh satu orang yang dirancang untuk merangsang atau membangkitkan suatu keadaan pada orang kedua atau kelompok orang yang berhubungan dengan suatu tujuan dan merupakan proses kunci dalam pengembangan program penyuluhan (Lewis, 1972). Motivasi didefinisikan sebagai kesediaan untuk mengeluarkan tingkat upaya yang tinggi ke arah tujuan organisasi, yang dikondisikan oleh kemampuan upaya itu untuk memenuhi sesuatu kebutuhan individual (Robbins, 1996). Menurut Lindner (1998), motivasi didefinisikan sebagai proses psikologis yang menentukan kegunaan dan arah perilaku, kecenderungan untuk bertindak dalam mencapai kebutuhan tertentu yang belum terpenuhi, suatu dorongan internal untuk memuaskan kebutuhan yang belum terpenuhi dan kemauan untuk mencapainya.

Mc Clelland mengemukakan teorinya yaitu Mc Clelland Achievement Motivation Theory atau Teori Motivasi Berprestasi Mc Clelland yang berpendapat bahwa karyawan mempunyai cadangan energi potensial, bagaimana energi dilepaskan dan digunakan tergantung pada kekuatan dorongan motivasi seseorang dan situasi serta peluang yang tersedia (Robbins, 1996). Hal-hal yang memotivasi seseorang adalah: (1) kebutuhan akan prestasi, (2) kebutuhan akan afiliasi, dan (3) kebutuhan akan kekuasaan. Kebutuhan akan prestasi merupakan daya penggerak yang memotivasi semangat bekerja seseorang sehingga akan mendorong seseorang untuk mengembangkan kreativitas dan mengarahkan semua kemampuan serta energi yang dimilikinya demi mencapai prestasi kerja yang maksimal. Karyawan akan antusias untuk berprestasi tinggi, asalkan kemungkinan untuk itu diberi kesempatan. Seseorang menyadari bahwa hanya dengan mencapai prestasi kerja yang tinggi akan dapat memperoleh pendapatan yang besar. Pendapatan yang besar akhirnya memiliki serta memenuhi kebutuhankebutuhannya.

Kebutuhanakanafiliasimenjadidayapenggerak yang akan memotivasi semangat bekerja seseorang sehingga merangsang gairah bekerja karyawan karena setiap orang menginginkan hal-hal: kebutuhan akan perasaan diterima oleh orang lain di lingkungan ia tinggal dan bekerja (sense of belonging), kebutuhan akan perasaan dihormati, karena setiap manusia merasa dirinya penting (sense of importance), kebutuhan akan perasaan maju dan tidak gagal (sense of achievement), dan kebutuhan akan perasaan ikut serta (sense of patcipation). Seseorang karena kebutuhan berafiliasi akan memotivasi dan mengembangkan dirinya serta memanfaatkan semua energinya untuk menyelesaikan tugas-tugasnya. Kebutuhan akan kekuasaan merupakan daya penggerak yang memotivasi semangat kerja 
karyawan sehingga akan merangsang dan memotivasi gairah kerja karyawan serta mengarahkan semua kemampuannya demi mencapai kekuasaan atau kedudukan yang terbaik. Ego manusia ingin lebih berkuasa dari manusia lainnya akan menimbulkan persaingan. Persaingan ditumbuhkan secara sehat oleh manajer dalam memotivasi bawahannya, supaya mereka termotivasi untuk bekerja giat. Kebutuhan akan pekerjaan juga diduga menjadi motivasi bagi seorang penyuluh pertanian. Pilihan akan suatu pekerjaan dan bertahan dalam pekerjaan tersebut karena keinginan mengabdikan diri ke masyarakat akan mendorong seseorang untuk bersemangat dalam pekerjaan yang dipilihnya. Hal yang tidak kalah penting adalah jumlah pendapatan yang diperoleh sesuai dengan harapan untuk memenuhi kebutuhan. Motivasi yang tinggi dari seorang penyuluh pertanian diharapkan dapat meningkatkan kemampuannya dalam melaksanakan tugasnya dengan baik.

Van den Ban dan Hawkins (1999) menyatakan bahwa persepsi adalah proses menerima informasi atau stimuli dari lingkungan dan mengubahnya ke dalam kesadaran psikologis. Seseorang tidak dituntut memahami psikologi persepsi manusia yang rumit, tetapi mereka diminta untuk menghargai timbulnya tafsiran yang berbeda serta bagaimana perbedaan tersebut mempengaruhi perilaku komunikasinya. Mardikanto (2009) menyatakan bahwa seorang penyuluh harus menghayati dan bangga terhadap profesinya serta merasakan bahwa kehadirannya untuk melaksanakan tugas penyuluhan sangat dibutuhkan masyarakat penerima manfaatnya. Berkaitan dengan masyarakat sasaran, penyuluh harus menyukai dan mencintai masyarakat sasarannya dalam arti selalu siap memberikan bantuan dan atau melaksanakan kegiatan-kegiatan demi berlangsungnya perubahan-perubahan usahatani maupun perubahan kehidupan masyarakat penerima manfaatnya. Persepsi yang baik seorang penyuluh pertanian terhadap lingkungannya diharapkan juga berpengaruh baik dalam meningkatkan kemampuannya.

Berkaitan dengan kompetensi, beberapa hasil penelitian menemukan bahwa tingkat kompetensi penyuluh pertanian PNS masih berada pada kategori rendah(Nuryanto, 2008; Anwas, 2011). Lalu bagaimana dengan kompetensi penyuluh THL TBPP? Hal ini menjadi alasan penting untuk diteliti. Berdasarkan hal yang diuraikan tersebut, maka tujuan penelitian ini adalah menganalisis tingkat kompetensi penyuluh THL TBPP dan faktor-faktor yang mempengaruhinya.

\section{Metode Penelitian}

Penelitian dilaksanakan dengan metode sensus. Lokasi penelitian di Kabupaten Garut, Jawa Barat. Populasi dalam penelitian ini adalah seluruh penyuluh THL TBPP di Kabupaten Garut sebanyak 119 orang. Data lapang dikumpulkan mulai bulan Juli-Oktober 2016. Kuesioner yang disusun untuk memperoleh data primer terdiri atas 79 pertanyaan untuk mendapatkan informasi mengenai karakteristik individu $\left(\mathrm{X}_{1}\right.$, motivasi kerja $\left(\mathrm{X}_{2}\right)$, persepsi terhadap dukungan pemerintah $\left(\mathrm{X}_{3}\right)$ dan kompetensi penyuluh THL TBPP (Y). Uji validitas dan reliabilitas instrumen penelitian dilakukan pada penyuluh THL TBPP di Kabupaten Bogor. Hasil uji coba memperlihatkan bahwa kuesioner layak digunakan dengan nilai uji validitas sebesar 0,362-0,877 dan nilai uji reliabilitas sebesar 0,638-0,858. Data mengenai kondisi penyuluh THL TBPP diperoleh dari Pusat Penyuluhan Pertanian dan Badan Pelaksana Penyuluhan Pertanian, Perikanan dan Kehutanan (BP4K) Kabupaten Garut. Data dianalisis menggunakan tabel frekuensi dan uji Regresi Linear Berganda dengan program SPSS 16. Sebelum data diolah menggunakan model regresi, dilakukan transformasi data menggunakan Method of Successive Interval (MSI).

\section{Hasil dan Pembahasan}

\section{Karateristik Individu}

Tabel 1 menunjukkan bahwa umur rata-rata penyuluh THL TBPP di Kabupaten Garut adalah 40,16 tahun masuk dalam kategori dewasa. Penyuluh THL TBPP yang berusia dewasa jika dibandingkan dengan penyuluh yang berusia muda biasanya memiliki fisik yang mulai kurang bugar namun memiliki pengalaman yang cukup luas dan rasa tanggungjawab yang mulai tinggi. Selain itu penyuluh THL TBPP yang berusia dewasa akan berpikir panjang untuk berganti profesi karena persaingan dalam mendapatkan pekerjaan sangat ketat. Pegawai yang berusia lebih tua dianggap kurang menguasai teknologi, namun kemungkinan untuk beralih pekerjaan lain sangat kecil (Wuriani et al., 2014). Pemerintah telah menjanjikan bahwa bagi penyuluh THL TBPP yang berusia 35 tahun ke bawah dapat mengikuti seleksi penerimaan Calon Pegawai Negeri Sipil (CPNS) sedangkan yang berusia di atas 35 tahun dapat mengikuti seleksi penerimaan Pegawai 
Tabel 1. Rataan Karakteristik Penyuluh THL TBPP di Kabupaten Garut

\begin{tabular}{lrlc}
\hline \multicolumn{1}{c}{ Variabel } & Rataan & \multicolumn{1}{c}{ Kategori } & Standar Deviasi \\
\hline Umur (tahun) & 40,16 & dewasa & 6,92 \\
Pendidikan formal (tahun) & 14,60 & Diploma III & 1,90 \\
Pelatihan 3 tahun terakhir (kali) & 3,00 & rendah & 2,32 \\
Jumlah desa binaan (desa) & 2,00 & sedang & 0,52 \\
Jumlah kelompok tani binaan (kelompok) & 10,00 & sedang & 3,73 \\
\hline
\end{tabular}

Pemerintah dengan Perjanjian Kerja (PPPK) sehingga diharapkan statusnya bisa lebih baik dibandingkan sebagai pegawai kontrak. Potensi penyuluh THL TBPP dari sisi usia dapat dioptimalkan dengan memanfaatkan sumberdaya manusia yang ada. Penyuluh THLTBPP yang berusia lebih tua dapat memberikan bimbingan dan masukan kepada yang lebih muda.

Pendidikan formal rata-rata telah ditempuh selama 14,60 tahun (setara DIII) diharapkan mampu menjadi bekal dalam melaksanakan tugasnya. Sebagian penyuluh THL TBPP masih berpendidikan SMA/SMK disebabkan pada saat penerimaan tahun 2007-2009, tingkat pendidikan minimal yang disyaratkan adalah SMK Pertanian, sehingga tingkat pendidikannya masih belum memadai untuk melaksanakan tugas melakukan kegiatan penyuluhan pertanian. Pemerintah perlu mendorong penyuluh THL TBPP untuk melanjutkan pendidikan ke jenjang yang lebih tinggi terutama bagi yang masih berusia muda untuk meningkatkan kemampuan dan memperluas wawasanPendidikan sebagai landasan untuk membentuk, mempersiapkan, membina dan mengembangkan kemampuan sumber daya manusia yang sangat menentukan dalam keberhasilan di masa yang akan datang (Ningrum et al., 2013). Pendidikan penyuluh akan sangat mempengaruhi kemampuan atau penguasaan materi yang diberikan, kemampuan mengembangkan ide, mengorganisasikan masyarakat sasaran serta kemampuan untuk menumbuhkan, menggerakkan dan memelihara partisipasi masyarakat (Mardikanto, 1993). Tingkat pendidikan yang tinggi dapat meningkatkan kompetensinya. Jenjang pendidikan memberikan konsekuensi pada peningkatan peran dan status sehingga banyak penyuluh pertanian yang melanjutkan pendidikan sarjana maupun S2 baik dengan biaya sendiri maupun beasiswa dari pemerintah (Suhanda et al., 2008).

Jumlah pelatihan dalam kurun waktu tiga tahun terakhir tergolong rendah yakni rata-rata hanya mengikuti 3 kali pelatihan disebabkan jumlah pelatihan yang diselenggarakan masih sangat terbatas karena keterbatasan anggaran dan lebih banyak diperuntukkan bagi penyuluh PNS. Hal ini harus menjadi perhatian bagi pemerintah mengingat penyuluh THL TBPP dan penyuluh PNS memilikitugas yang sama melaksanakan kegiatan penyuluhan pertanian sehingga perlu jumlah pelatihan yang sama. Pelatihan yang diikuti oleh penyuluh THL TBPP sebagian besar hanya memenuhi undangan pelatihan yang dilakukan oleh Balai Besar Pelatihan Pertanian Pemerintah Pusat. Pelatihan memiliki fungsi untuk meningkatkan keterampilan dan pengetahuan penyuluh dalam waktu yang relatif lebih singkat. Di dalam pelatihan diciptakan suatu lingkungan di mana para penyuluh dapat memperoleh atau mempelajari sikap, kemampuan, keahlian, pengetahuan, dan perilaku yang spesifik yang berkaitan dengan pekerjaan. Pelatihan biasanya terfokus pada penyediaan keahlian-keahlian khusus atau membantu peserta mengoreksi kelemahan-kelemahan dalam kinerja mereka. Kebutuhan pelatihan harus sangat diperhatikan dan harus didukung dengan metode pelatihan, materi pelatihan, pelatih atau pengajar, dan fasilitas pelatihan yang baik agar memberikan hasil yang maksimal (Ningrum et al., 2013). Pelatihan merupakan salah satu upaya fasilitasi meningkatkan kompetensi (pengetahuan dan keterampilan) (Cyr, 2008). Semakin banyak jumlah pelatihan yang diikuti oleh penyuluh pertanian maka semakin banyak pengetahuan serta keterampilan yang didapatkan oleh penyuluh (Putri et al., 2016).

Penyuluh THL TBPP rata-rata membina 2 desa disebabkan terbatasnya jumlah penyuluh pertanian. Hal ini tentunya cukup memberatkan karena jarak antar desa kadang-kadang cukup jauh sehingga memerlukan banyak waktu dan biaya operasional untuk mengunjungi desa binaannya. Semakin banyak desa binaan akan semakin terbatas seorang penyuluh untuk meningkatkan pengetahuan dan ketrampilannya 
dalam rangka mempersiapkan kegiatan penyuluhan. Idealnya satu penyuluh pertanian hanya membina satu desa binaan supaya tersedia waktu yang cukup memadai untuk belajar dalam rangka meningkatkan pengetahuan dan keterampilannya. Konsekuensi dari kondisi ini sebagaimana disampaikan Mardikanto (1993) bahwa kegiatan penyuluhan pertanian harus dilaksanakan dengan menggunakan sedikit penyuluh yang andal.

Penyuluh THL TBPP rata-rata membina 10 kelompok tani. Hal ini tentu sangat memberatkan dalam hal membagi waktu untuk mempersiapkan materi penyuluhan dan melakukan kunjungan lapang ke masing-masing kelompok tani guna menyampaikan materi penyuluhan. Penyuluh THL TBPP dengan jumlah kelompok tani binaan yang cukup banyak, tidak akan memiliki waktu yang cukup memadai untuk menambah dan memperdalam pengetahuan dan keterampilannya dalam rangka menjaga kualitas kegiatan penyuluhannya sehingga dikhawatirkan tidak akan mengutamakan kualitas melainkan hanya kuantitas penyuluhannya saja. Departemen Pertanian telah menyatakan bahwa idealnya satu penyuluh pertanian hanya membina 6-8 kelompok tani (Hernanda, 2015).

\section{Motivasi Kerja}

Secara umum, nilai motivasi dari penyuluh THL TBPP berada pada kriteria tinggi dengan nilai rata-rata 47,14. Motivasi diukur berdasarkan tingkat kebutuhan untuk berprestasi, berafiliasi dan tingkat kebutuhan akan pekerjaan. Tingkat kebutuhan akan pekerjaan masuk dalam kategori rendah sedangkan tingkat kebutuhan untuk berprestasi masuk dalam kategori tinggi. Rataan indikator motivasi penyuluh THL TBPP di Kabupaten Garut dapat dilihat pada Tabel 2.
Tingkat kebutuhan untuk berprestasi penyuluh THL TBPP sebagian besar berada pada kategori tinggi dengan nilai rata-rata 21,04. Hal ini sesuai dengan hasil penelitian Hernanda (2015) yang menemukan bahwa penyuluh THL TBPP menganggap prestasi merupakan hal yang penting untuk mendorong mereka mencapai target yang telah ditetapkan. Penyuluh THL TBPP memiliki keinginan yang besar untuk melanjutkan pendidikan yang lebih tinggi dan melaksanakan tugas dengan sebaik-baiknya supaya mendapatkan rekomendasi perpanjangan kontrak. Hal yang masih menjadi kendala adalah penyuluh THL TBPP kurang memiliki keinginan besar untuk bersaing dan mengungguli sesama penyuluh THL TBPP karena merasa sebagai teman seperjuangan. Kebutuhan akan prestasi merupakan daya penggerak yang memotivasi semangat bekerja seseorang sehingga akan mendorong seseorang untuk mengembangkan kreativitas dan mengarahkan semua kemampuan serta energi yang dimilikinya demi mencapai prestasi kerja yang maksimal (Robbins, 1996).

Tingkat kebutuhan untuk berafiliasi masuk dalam kategori sangat tinggi dengan nilai rata-rata 21,17. Hal ini sesuai dengan hasil penelitian Hernanda (2015) yang menemukan bahwa indikator kebutuhan untuk berafiliasi/berhubungan dengan orang lain memiliki nilai tertinggi dibandingkan indikator motivasi lainnya. Penyuluh THL TBPP banyak terlibat dalam beberapa organisasi diantaranya Forum Komunikasi THL TBPP, Perhimpunan Penyuluh Pertanian Indonesia (Perhiptani) dan Himpunan Kerukunan Tani Indonesia (HKTI). Mereka aktif dalam pertemuan rutin kelompok tani dan selalu hadir dalam Musyawarah Perencanaan dan Pembangunan Desa (Musrenbangdes). Mereka memiliki keinginan yang besar untuk berpartisipasi membantu petani meningkatkan kesejahteraan, membangun jejaring kerjasama dalam hal permodalan dan pemasaran,

Tabel 2. Rataan Indikator Motivasi Penyuluh THL TBPP di Kabupaten Garut

\begin{tabular}{lclc}
\hline \multicolumn{1}{c}{ Indikator } & Rataan & \multicolumn{1}{c}{ Kategori } & Standar Deviasi \\
\hline Tingkat kebutuhan untuk berprestasi & 21,04 & tinggi & 2,31 \\
Tingkat kebutuhan untuk berafiliasi & 21,17 & sangat tinggi & 2,20 \\
Tingkat kebutuhan akan pekerjaan & 4,93 & rendah & 1,04 \\
Total & 47,14 & tinggi & 4,15 \\
\end{tabular}


mendapatkan respon positif dan dihargai petani dan menjadi tempat berkonsultasi mencari solusi bagi petani. Kebutuhan akan afiliasi menjadi daya penggerak yang akan memotivasi semangat bekerja seseorang sehingga merangsang gairah bekerja karyawan karena setiap orang menginginkan hal-hal: kebutuhan akan perasaan diterima oleh orang lain di lingkungan ia tinggal dan bekerja (sense of belonging), kebutuhan akan perasaan dihormati, karena setiap manusia merasa dirinya penting (sense of importance), kebutuhan akan perasaan maju dan tidak gagal (sense of achievement), dan kebutuhan akan perasaan ikut serta (sense of participation). Seseorang karena kebutuhan berafiliasi akan memotivasi dan mengembangkan dirinya serta memanfaatkan semua energinya untuk menyelesaikan tugas-tugasnya (Robbins, 1996).

Tingkat kebutuhan akan pekerjaan masuk dalam kategori rendah dengan nilai rata-rata 4,93. Penyuluh THL TBPP memilih pekerjaan sebagai penyuluh kontrak dan sejak tahun 2007 hingga tahun 2016 masih bertahan dalam pekerjaannya bukan semata-mata karena ingin mengabdikan ilmu bidang pertanian yang dimilikinya untuk membantu petani tetapi karena keterbatasan lapangan pekerjaan lain di Kabupaten Garut. Hal lain yang menyebabkan nilai indikator ini rendah adalah kecilnya honor yang diterima untuk menunjang pelaksanaan tugasnya. Pada tahun 2016 besarnya honor penyuluh THL TBPP tingkat pendidikan SMK senilai Rp1.200.000,00, DIII senilai Rp1.500.000,00 dan S1 senilai Rp2.000.000,00. Pemerintah pusat hanya memberikan honor selama 10 bulan sedangkan honor selama dua bulan yang menjadi tanggungjawab pemerintah daerah Kabupaten Garut tidak diberikan karena keterbatasan anggaran. Kondisi ini sama dengan hasil penelitian Firmansyah et al., (2015) yang menemukan bahwa gaji dan tunjangan operasional penyuluh kurang sesuai dengan kondisi kerja yang mereka hadapi serta kurang menunjang penyuluh dalam melaksanakan tugas pokok mereka secara maksimal seperti kunjungan ke wilayah binaan yang jauh dan membuat materi penyuluhan sesuai dengan tuntutan lapangan. Hubeis (2009) menemukan bahwa gaji yang diterima penyuluh tidak memungkinkan mereka memberdayakan diri dalam menyiapkan materi penyuluhan, sesuai dengan tuntutan lapangan. Pemerintah pusat perlu melakukan upaya untuk meningkatkan motivasi penyuluh THL TBPP dalam rangka mengabdikan ilmunya untuk membantu petani antara lain dengan menambah jumlah honor yang disesuaikan dengan peraturan menteri keuangan yakni tingkat pendidikan SMA senilai Rp2.100.000,00, DIII senilai Rp2.400.000,00 dan S1/DIV senilai Rp2.600.000,00 (Kemenkeu 2014) sedangkan pemerintah daerah perlu mengalokasikan anggaran untuk membayar honor penyuluh THL TBPP selama dua bulan yang disesuaikan dengan Upah Minimum Kabupaten/Kota.

\section{Persepsi}

Secara umum, nilai persepsi penyuluh THL TBPP berada pada kriteria baik dengan nilai ratarata 84,18 (Tabel 3). Persepsi diukur berdasarkan pandangannya tentang pekerjaannya, masyarakat sasarannya, keberadaan penyuluh PNS dan dukungan yang diberikan pemerintah. Sebagian besar penyuluh THL TBPP memiliki persepsi yang sangat baik terhadap masyarakat sasarannya. Rataan indikator persepsi penyuluh THL TBPP di Kabupaten Garut dapat dilihat pada Tabel 3.

Persepsi penyuluh THL TBPP tentang pekerjaannya masuk dalam kategori baik dengan nilai rata-rata 20,96. Mereka merasa bangga dan senang memiliki pekerjaan sebagai penyuluh kontrak serta tetap bersemangat meskipun tidak yakin bahwa pekerjaannya tersebut dapat menjamin masa depannya

Tabel 3. Rataan Indikator Persepsi Penyuluh THL TBPP di Kabupaten Garut

\begin{tabular}{lccc}
\hline \multicolumn{1}{c}{ Indikator } & Rataan & Kategori & Standar Deviasi \\
\hline Persepsi tentang pekerjaannya & 20,96 & baik & 2,23 \\
Persepsi tentang masyarakat sasaran & 13,18 & sangat baik & 1,33 \\
Persepsi tentang keberadaan penyuluh PNS & 28,31 & baik & 3,02 \\
Persepsi tentang dukungan pemerintah & 21,72 & baik & 2,09 \\
Total & 84,18 & baik & 6,18 \\
\hline
\end{tabular}


karena statusnya hanya sebagai tenaga kontrak. Di sisi lain, mereka menyadari bahwa pekerjaannya sangat berpengaruh terhadap kesejahteraan petani. Mardikanto (2009) menyatakan bahwa seorang penyuluh harus menghayati dan bangga terhadap profesinya serta merasakan bahwa kehadirannya untuk melaksanakan tugas penyuluhan sangat dibutuhkan masyarakat penerima manfaatnya.

Persepsi tentang masyarakat sasaran masuk dalam kategori sangat baik dengan nilai rata-rata 13,18. Penyuluh THL TBPP selalu berupaya menjalin hubungan yang baik dengan masyarakat sasaran, sehingga respon petani cukup baik. Mereka juga merasa masih minim pengalaman dalam usaha tani sehingga merasa terbuka terhadap masukan dan saran serta akan berupaya memperbaiki kelemahan dan kekurangan yang ada. Seorang penyuluh harus menyukai dan mencintai masyarakat sasarannya dalam arti selalu siap memberikan bantuan dan atau melaksanakan kegiatan-kegiatan demi berlangsungnya perubahan-perubahan usahatani maupun perubahan kehidupan masyarakat penerima manfaatnya. Sikap seperti ini harus dimiliki oleh seorang penyuluh dalam memandang tugasnya sebagai seorang pelaksana kegiatan penyuluhan dalam memandang masyarakat sasarannya. Hal ini sesuai dengan yang disampaikan Mardikanto (2009) yang menyatakan bahwa penyuluh harus menyukai dan mencintai masyarakat sasarannya, selalu siap memberikan bantuan demi berlangsungnya perubahan-perubahan usaha tani maupun perubahan perubahan kehidupan masyarakat sasarannya.

Persepsi tentang keberadaan penyuluh PNS masuk dalam kategori baik dengan nilai rata-rata 28,31. Penyuluh THL TBPP menganggap keberadaan penyuluh PNS sangat penting sebagai tempat bertanya terkait permasalahan yang dihadapi namun interaksi dan kepedulian penyuluh PNS terhadap penyuluh THL TBPP masih dirasakan kurang. Hal ini disebabkan penyuluh PNS banyak yang sudah mendekati masa pensiun sehingga sudah kurang aktif dalam beberapa kegiatan. Selain itu perbedaan status penyuluh PNS dan penyuluh THL TBPP menyebabkan adanya sedikit jarak diantara mereka. Berkaitan dengan hubungan antara penyuluh THL TBPP dengan penyuluh PNS, pemerintah telah menetapkan tata kerja penyuluh THL TBPP diantaranya: (1)menyusun rencana kerja tahunan penyuluh THL TBPP yang disahkan oleh Kepala/ Koordinator Balai Penyuluhan; (2)melaksanakan tugas sesuai rencana kerja tahunan dengan bimbingan dari
Kepala/Koordinator Balai Penyuluhan dan Penyuluh Pertanian PNS; (3) dalam melaksanakan tugasnya diwajibkan melapor kepada Kepala/Koordinator Balai Penyuluhan; (4) dilarang melaksanakan kegiatan di luar tugas dan fungsinya; (5) membuat laporan pelaksanaan kegiatan penyuluhan setiap bulan kepada Kepala/Koordinator Balai Penyuluhan (Kementan, 2011). Pemerintah melalui Kepala/ Koordinator Balai Penyuluhan dapat melakukan beberapa kegiatan untuk mengatasi kurangnya interaksi dan kepedulian penyuluh PNS terhadap penyuluh THL TBPP dengan mengadakan kegiatan bersama yang melibatkan seluruh penyuluh di tingkat balai penyuluhan kecamatan seperti senam pagi bersama dan kerja bakti untuk memperkuat keakraban dan mengurangi jarak antara penyuluh PNS dan penyuluh THL TBPP.

Persepsi terhadap dukungan pemerintah masuk dalam kategori baik dengan nilai rata-rata 21,72. Dukungan pemerintah adalah segala dukungan dan fasilitas yang diberikan kepada penyuluh THL TBPP untuk mendukung pelaksanaan kegiatan penyuluhan. Keinginan penyuluh THL TBPP untuk diangkat menjadi penyuluh tetap sangat tinggi dan merasa yakin bahwa pemerintah akan mengangkat mereka sebagai penyuluh Pegawai Negeri Sipil (PNS) atau Pegawai Pemerintah dengan Perjanjian Kerja (P3K). Pemerintah telah menjanjikan bahwa penyuluh THL TBPP yang berusia di bawah 35 tahun dapat mengikuti seleksi penerimaan PNS sedangkan penyuluh THL TBPP yang berusia di atas 35 tahun dapat mengikuti seleksi penerimaan $\mathrm{P} 3 \mathrm{~K}$. Hal ini menimbulkan kecemburuan pada penyuluh THL TBPP yang berusia di atas 35 tahun. Mereka menginginkan supaya hak untuk mengikuti seleksi penerimaan PNS disamakan karena telah memulai tugas sebagai penyuluh THL TBPP secara bersama-sama. Berkaitan dengan fasilitas kegiatan penyuluhan, hal yang masih kurang menurut mereka adalah fasilitas sarana kantor di BP3K yaitu komputer dengan jaringan internet, anggaran untuk kaji terap, materi penyuluhan berupa brosur dan leaflet. BP3K di Kabupaten Garut telah memiliki lahan untuk demplot/percontohan, namun anggaran untuk pelaksanaan kegiatan kaji terap tidak tersedia sehingga lahan percontohan tidak dapat dimanfaatkan dengan baik.

\section{Kompetensi}

Secara umum, nilai kompetensi penyuluh THL 
TBPP berada pada kategori rendah dengan nilai rata-rata 32,49. Kompetensi diukur berdasarkan pengetahuan tentang potensi wilayah, kebutuhan petani, pengenalan informasi teknologi, pengetahuan tentang komunikasi efektif dan penyusunan laporan kegiatan. Sebagian besar penyuluh THL TBPP memiliki pengetahuan yang rendah terhadap beberapa indikator kompetensitersebut disebabkan terbatasnya fasilitas yang disediakan oleh pemerintah dalam mendukung pelaksanaan kegiatan penyuluhan pertanian diantaranya jumlah pelatihan yang sangat kurang dan jumlah honor yang sangat kecil. Rataan indikator kompetensi penyuluh THL TBPP di Kabupaten Garut dapat dilihat pada Tabel 4.

Pengetahuan sebagian besar penyuluh THL TBPP tentang potensi wilayah berada pada kategori rendah dengan nilai rata-rata 7,03. Mereka tidak mengetahui unsur-unsur data potensi wilayah dalam sebuah kegiatan penyuluhan, tidak mengetahui bahwa data luas lahan pertanian, data kelompok tani termasuk data potensi wilayah yang diperoleh secara langsung (data primer), tidak mengetahui bahwa komoditas unggulan merupakan komoditas unggul yang menguntungkan dan layak dikembangkan pada suatu daerah. Hal ini sama dengan kompetensi penyuluh PNS (Anwas et al., 2010) yang ditemukan bahwa tingkat kompetensi penyuluh PNS dilihat dari dimensi kemampuan pemahaman potensi wilayah cenderung rendah. Namun kondisi tersebut berbeda dengan hasil penelitian Nuryanto (2008) yang menemukan bahwa penyuluh cukup memahami potensi sumberdaya alam dan komoditas-komoditas unggulan yang ada di wilayah kerjanya sebagaimana pendapat Sumardjo (Nuryanto, 2008) yang menyatakan bahwa pemahaman potensi wilayah merupakan salah satu kompetensi yang harus dimiliki oleh seorang penyuluh pertanian untuk mendukung pelaksanaan pekerjaannya. Menurut Mardikanto (2009), pemahaman potensi wilayah kerja merupakan persyaratan mutlak bagi seorang penyuluh. Dengan memahami potensi wilayah kerja, dapat membantu penyuluh untuk memahami keadaan masyarakat, lingkungan dan budaya sasaran penyuluhan. Selain dari itu dapat membantu penyuluh untuk memahami permasalahan yang dihadapi petani, kendala-kendala dan faktor-faktor pendukung kegiatan penyuluhan. Sehubungan dengan rendahnya pemahaman penyuluh THL TBPP terhadap potensi wilayah, maka perlu dilakukan upaya untuk meningkatkan pemahaman terhadap potensi wilayah melalui kegiatan pelatihan tentang inventarisasi potensi wilayah.

Pengetahuan sebagian besar penyuluh THL TBPP terhadap kebutuhan petani masuk dalam kategori rendah dengan nilai rata-rata 7,21. Mereka tidak mengetahui cara melakukan inventarisir kebutuhan dan permasalahan yang dihadapi petani. Selain dari itu, mereka tidak mengetahui bahwa rencana kerja penyuluh pertanian adalah hasil akhir dari kegiatan identifikasi potensi wilayah, agroekosistem dan kebutuhan teknologi petani. Hal ini bermakna bahwa penyuluh THL TBPP belum mengetahui kebutuhan petani dan belum membantu upaya memecahkan permasalahan-permasalahan yang dihadapi petani. Kondisi ini berbeda dengan kompetensi penyuluh pertanian PNS hasil penelitian Nuryanto (2008) yang menemukan bahwa kompetensi penyuluh dalam memahami kebutuhan petani relatif baik, kegiatan penyuluhan berpihak pada kebutuhan petani dan mampu memberikan kepuasan kepada petani dengan cara memenuhi sebagian atau seluruh kebutuhan dan harapan petani. Hal ini sesuai pendapat Sumardjo (Nuryanto, 2008) yang menyatakan bahwa pemahaman kebutuhan petani merupakan salah satu kompetensi yang harus dimiliki oleh seorang penyuluh pertanian untuk mendukung pelaksanaan

Tabel 4. Rataan Indikator Kompetensi Penyuluh THL TBPP di Kabupaten Garut

\begin{tabular}{lrlc}
\hline \multicolumn{1}{c}{ Indikator } & Rataan & \multicolumn{1}{c}{ Kategori } & Standar Deviasi \\
\hline Pengetahuan potensi wilayah & 7,03 & rendah & 1,00 \\
Pengetahuan kebutuhan petani & 7,21 & rendah & 1,19 \\
Pengenalan teknologi informasi & 3,30 & tinggi & 0,50 \\
Pengetahuan komunikasi efektif & 11,24 & tinggi & 1,60 \\
Pengetahuan menyusun laporan & 3,71 & sangat rendah & 0,80 \\
Total & 32,49 & rendah & 3,40 \\
\hline
\end{tabular}


pekerjaannya. Ibrahim (2001) mengemukakan beberapa kebutuhan petani yaitu: (1) kebutuhan untuk meningkatkan produktivitas, (2) kebutuhan keamanan usaha, (3) kebutuhan kesinambungan usaha, (4) kebutuhan identitas petani. Slamet (Nuryanto, 2008) menekankan bahwa kebutuhan atau kepentingan petani harus selalu menjadi titik pusat perhatian penyuluhan pertanian. Kebutuhan petani sederhana yaitu mendapatkan imbalan yang wajar dan adil dari jerih payah dan pengorbanan lainnya dalam berusahatani, dan mendapatkan kesempatan untuk memberdayakan dirinya sehingga mampu mensejajarkan dirinya dengan unsur masyarakat lainnya. Dengan demikian pemahaman penyuluh THL TBPP terhadap kebutuhan petani masih harus ditingkatkan melalui pelatihan tentang inventarisasi kebutuhan petani dan upaya pemecahan masalah yang dihadapi oleh petani.

Pengenalan penyuluh THL TBPP terhadap teknologi informasi masuk dalam kategori tinggi dengan nilai rata-rata 3,30. Mereka cukup memahami bahwa materi penyuluhan dapat diunduh menggunakan komputer melalui jaringan internet namun kurang memahami tentang cyber extention yang telah disediakan oleh pemerintah sebagai sumber informasi pertanian. Hal ini terjadi karena penyuluh THL TBPP masih jarang memanfaatkan informasi teknologi dalam kegiatan penyuluhan pertanian. Hanya sebagian kecil penyuluh THL TBPP yang memanfaatkan telepon seluler untuk mengakses informasi dalam mempersiapkan materi penyuluhan sedangkan sebagian yang lain bertanya kepada sesama penyuluh THL TBPP. Pemerintah perlu mendorong penyuluh THL TBPP untuk mempelajari dan memanfaatkan teknologi informasi sebagaimana yang dikemukakan Sumardjo (Nuryanto, 2008) bahwa penyuluh harus memiliki kemampuan akses informasi dan keinovatifan atau penguasaan teknologi informasi karena petani sangat membutuhkan informasi dan teknologi untuk pengambilan keputusan. Menurut van de Ban dan Hawkins (1999), informasi yang dibutuhkan oleh petani meliputi laporan hasil penelitian, data pasar, data tentang pertumbuhan dan proses pengelolaan lahan pertaniannya dan yang serupa sebagai pembanding. Informasi ini digunakan untuk memilih teknologi produksi yang paling menguntungkan, menciptakan kondisi pertumbuhan yang optimal untuk tanaman dan ternaknya, menentukan anggaran pengeluaran dan melihat usaha yang paling menguntungkan serta memutuskan waktu dan tempat menjual hasilnya. Dengan berkembangnya teknologi informasi, penyuluh dapat memberikan petunjuk kepada petani secara cepat dan tepat untuk mengembangkan usahanya. Kondisi ini berbeda dengan hasil penelitian Nuryanto (2008) terhadap kompetensi penyuluh pertanian PNS yang menemukan tingkat pengetahuan penyuluh dalam mengakses informasi tergolong rendah, pengetahuan penyuluh tentang sumber-sumber informasi dan caracara mengakses media internet untuk pengembangan kegiatan penyuluhan masih tergolong rendah. Penyuluh THL TBPP yang direkrut pada tahun 2007 hingga 2009 rata-rata berusia lebih muda dibandingkan penyuluh PNS, sehingga mereka lebih banyak mengenal informasi dan teknologi. Namun sayangnya hal ini kurang didukung dengan fasilitas yang memadai untuk menunjang kegiatan penyuluhan pertanian. Pemerintah pusat sebetulnya telah memberikan fasilitas seperangkat komputer dan modem pada setiap BP3K untuk membantu penyelenggaraan kegiatan penyuluhan, namun tidak adanya anggaran untuk biaya operasional menyebabkan fasilitas tersebut tidak dapat dimanfaatkan secara maksimal.

Pengetahuan penyuluh THL TBPP terhadap komunikasi yang efektif masuk dalam kategori tinggi dengan nilai rata-rata 11,24. Mereka cukup memahami bahwa materi penyuluhan adalah pesan yang ingin disampaikan oleh penyuluh pertanian kepada petani, yang harus disampaikan dengan bahasa yang mudah dipahami agar petani mau dan mampu menerapkan inovasi baru. Namun demikian, mereka belum memahami bahwa materi penyuluhan tidak harus berupa informasi terbaru dan umumnya disajikan kepada petani dalam bentuk poster dan leaflet. Hal ini hampir sama dengan hasil penelitian terhadap kompetensi penyuluh pertanian PNS (Nuryanto, 2008; Anwas, 2011) yang menemukan bahwa penyuluh memiliki kemampuan untuk berkomunikasi secara efektif sehingga sesuai dengan pendapat Sumardjo (Nuryanto, 2008) yang menyatakan bahwa penyuluh harus memiliki kemampuan berkomunikasi secara konvergen dan efektif berkaitan dengan penyelenggaraan penyuluhan pertanian. Mardikanto (2009) menekankan bahwa agar komunikasi dapat berjalan secara efektif, perlu diperhatikan beberapa hal. Pertama, bagi penyuluh, perlu: (a) meningkatkan keterampilannya berkomunikasi, (b) menyampaikan pesan dengan cara/bahasa yang mudah dipahami, (c) bersikap baik, (d) memahami, mengikuti atau 
setidak-tidaknya tidak menyinggung nilai-nilai sosial budaya sasaran. Kedua, pesan, (a) mengacu kepada kebutuhan masyarakat dan disampaikan pada saat sedang dan atau segera akan dibutuhkan, (b) disampaikan dalam bahasa yang mudah dipahami, (c) tidak memerlukan pengorbanan yang memberatkan, (d) memberikan harapan peluang keberhasilan yang tinggi, dengan tingkat manfaat yang merangsang, (e) dapat diterapkan sesuai dengan kondisi (pengetahuan, keterampilan, sumberdaya yang dimiliki/dapat diusahakan) masyarakatnya. Ketiga, unsur media/ saluran komunikasi yang digunakan harus bebas dari gangguan, baik gangguan teknis maupun gangguan sosial budaya dan psikologi. Pilihan media yang digunakan perlu disesuaikan dengan selera masyarakat setempat dengan mempertimbangkan kemampuan sumberdaya (dana, keterampilan dan peralatan yang tersedia).

Pengetahuan penyuluh THL TBPP dalam hal penyusunan laporan kegiatan penyuluhan masuk dalam kategori sangat rendah dengan nilai rata-rata 3,71. Laporan kegiatan penyuluhan adalah penyampaian secara tertulis fakta-fakta yang terjadi dalam kegiatan penyuluhan pertanian yang telah dilaksanakan. Penyuluh THL TBPP tidak mengetahui bahwa laporan kegiatan penyuluhan harus disusun secara mandiri dengan menuliskan kegiatan-kegiatan yang dilaksanakan pada aktivitas penyuluhan pertanian. Mereka juga tidak mengetahui bahwa laporan pelaksanaan kegiatan penyuluhan pertanian adalah bentuk pertanggungjawaban pelaksanaan tugas. Hal ini disebabkan laporan kegiatan penyuluhan pertanian selama ini masih sebatas formalitas untuk persyaratan pencairan honor dan biaya operasional sehingga pemahaman tentang penyusunan laporan kegiatan yang baik tidak diperhatikan. Selama ini kegiatan pelaporan belum menjadi prioritas dalam pelaksanaan penyuluhan pertanian dan hanya dilakukan sesekali saja (Hernanda et al., 2015). Pengetahuan penyuluh THL TBPP tentang penyusunan laporan kegiatan masih dapat ditingkatkan melalui kegiatan pelatihan non teknis.

\section{Faktor-faktor yang Mempengaruhi Kompetensi}

Kompetensi diduga dipengaruhi oleh karakteristik (umur, pendidikan formal, pelatihan, jumlah desa, jumlah kelompok tani), motivasi dan persepsi. Hasil analisis korelasi Pearson menunjukkan bahwa terdapat hubungan sangat nyata dan positif antara pendidikan formal, jumlah desa binaan, jumlah kelompok tani binaan, motivasi dan persepsi dengan kompetensi penyuluh THL TBPP seperti dapat dilihat pada Tabel 5.

Pada Tabel 5 dapat dilihat bahwa faktor pendidikan formal, jumlah desa, jumlah kelompok tani, motivasi dan persepsi memiliki hubungan yang cukup kuat dengan nilai korelasi (r) masing-masing 0,793, $0,769,0,735,0,951$ dan 0,894 . Hal ini bermakna bahwa semakin baik atau semakin tinggi dukungan kelima faktor ini maka tingkat kompetensi akan menjadi semakin baik. Faktor umur dan jumlah pelatihan memiliki hubungan tidak nyata dengan kompetensi. Hal ini berarti faktor umur dan jumlah pelatihan yang diikuti belum belum memberikan dukungan dalam meningkatkan kompetensi penyuluh THL TBPP.

Kompetensi yang diteliti pada penelitian ini terdiri dari lima variabel yakni pengetahuan terhadap

Tabel 5. Nilai Koefisien Korelasi (r) Faktor-faktor yang Berhubungan dengan Kompetensi Penyuluh THL TBPP di Kabupaten Garut

\begin{tabular}{lllcc}
\hline No & & Variabel Bebas & Koefisien Korelasi (r) & Nilai Probabilitas Sig. (2-tailed) \\
\hline 1 & $\mathrm{X} 1 ._{1}$ & Umur & $-0,178$ & 0,064 \\
2 & $\mathrm{X} 1{ }_{2}$ & Pendidikan formal & $0,793^{* *}$ & 0,000 \\
3 & $\mathrm{X} 1 ._{3}$ & Pelatihan & $-0,028$ & 0,774 \\
4 & $\mathrm{X} 1 ._{4}$ & Jumlah Desa & $0,769^{* *}$ & 0,000 \\
5 & $\mathrm{X} 1 ._{5}$ & Jumlah Kelompok tani & $0,735^{* *}$ & 0,000 \\
6 & $\mathrm{X} 2$ & Motivasi & $0,951^{* *}$ & 0,000 \\
7 & $\mathrm{X} 3$ & Persepsi & $0,894^{* *}$ & 0,000 \\
\hline
\end{tabular}

Keterangan : ** sangat nyata pada $\alpha=0,01$ 
Tabel 6. Nilai koefisien Regresi (r) Faktor-faktor yang Berpengaruh terhadap Kompetensi Penyuluh THL TBPP di Kabupaten Garut

\begin{tabular}{|c|c|c|c|c|c|c|c|}
\hline \multirow{3}{*}{ No } & \multirow{3}{*}{$\begin{array}{c}\text { Variabel Bebas } \\
\text { (X) }\end{array}$} & \multicolumn{6}{|c|}{ Kompetensi } \\
\hline & & $\begin{array}{c}\text { Potensi } \\
\text { wilayah } \\
(\text { Y1.. })\end{array}$ & $\begin{array}{l}\text { Kebutuhan } \\
\text { petani }\left(\mathrm{Y} 1 ._{2}\right)\end{array}$ & $\begin{array}{c}\text { Informasi } \\
\text { teknologi } \\
\left(Y 1_{3}\right)\end{array}$ & $\begin{array}{l}\text { Komunikasi } \\
\text { efektif (Y1. })\end{array}$ & $\begin{array}{c}\text { Penyusunan } \\
\text { laporan } \\
\left(\mathrm{Y} 1 ._{5}\right)\end{array}$ & $\begin{array}{l}\text { Total } \\
\text { (Y1) }\end{array}$ \\
\hline & & $\boldsymbol{\beta}$ & $\beta$ & $\boldsymbol{\beta}$ & $\boldsymbol{\beta}$ & $\beta$ & $\beta$ \\
\hline 1 & $\operatorname{Umur}\left(\mathrm{X} 1_{.1}\right)$ & 0,019 & 0,030 & $-0,005$ & $-0,051$ & $-0,026$ & $-0,033$ \\
\hline 2 & Pendidikan $(\mathrm{X} 1.2)$ & $-0,064$ & 0,303 & 0,033 & 0,426 & $-0,272$ & 0,426 \\
\hline 3 & Pelatihan $\left(\mathrm{X} 1 .{ }_{3}\right)$ & 0,063 & 0,039 & 0,008 & $-0,149 *$ & $-0,020$ & $-0,059$ \\
\hline 4 & Jumlah desa $\left(\mathrm{X} 1 ._{4}\right)$ & 0,480 & $-0,920$ & 0,225 & $-1.653^{*}$ & 0,184 & $-1,685^{*}$ \\
\hline 5 & Jumlah kelompok & 0,080 & 0,084 & 0,030 & $-0,008$ & 0,068 & $0,254 * *$ \\
\hline 6 & $\begin{array}{l}\operatorname{tani}\left(X 1 ;{ }^{\prime}\right) \\
\text { Motivasi }(X 2)\end{array}$ & 0,062 & $0,181^{*}$ & 0,013 & $0,390 * *$ & 0,149 & $0,795^{* *}$ \\
\hline 7 & Persepsi (X3) & 0,051 & 0,004 & 0,002 & $-0,025$ & 0,002 & 0,033 \\
\hline & Konstanta & 0,064 & $-4,393$ & 3,241 & $-0,989$ & 1,710 & $-0,377$ \\
\hline & $\mathrm{R}^{2}$ & 0,459 & 0,462 & 0,165 & 0,627 & 0,346 & 0,930 \\
\hline
\end{tabular}

Keterangan : ** sangat nyata pada $\alpha=0,01$

* nyata pada $\alpha=0,05$

potensi wilayah, kebutuhan petani, pengenalan teknologi informasi, pengetahuan komunikasi efektif dan pengetahuan terhadap penyusunan laporan kegiatan. Hasil analisis regresi linier berganda untuk menganalisis pengaruh karakteristik individu, motivasi kerja dan persepsi terhadap masing-masing variabel kompetensi dapat dilihat pada Tabel 6 .

Berdasarkan Tabel 6 ditemukan bahwa pengetahuan THL TBPP terhadap kebutuhan petani dipengaruhi oleh motivasi. Motivasi berpengaruh nyata terhadap pengetahuan kebutuhan petani dengan nilai koefisien regresi 0,181 . Hal ini bermakna bahwa semakin besar motivasi seorang THL TBPP untuk berafiliasi dalam rangka membantu petani meningkatkan kesejahteraannya maka akan mendorongnya untuk meningkatkan pengetahuan sehingga pengetahuannya tentang kebutuhan petani akan semakin meningkat. Persamaan regresi untuk variabel kompetensi pengetahuan THL TBPP terhadap kebutuhan petani dapat dituliskan sebagai berikut: $\mathrm{Y} 1.2=-4,393+0,181 \mathrm{X} 2$

Keterangan: $\quad \mathrm{Y}_{._{2}}=$ Pemahaman kebutuhan petani $\mathrm{X} 2{ }^{2}=$ Motivasi

Berdasarkan persamaan tersebut dapat disampaikan bahwa untuk meningkatkan pengetahuan THL TBPP terhadap kebutuhan petani dapat dilakukan dengan meningkatkan motivasi untuk berafiliasi atau berhubungan dengan orang lain yang dalam hal ini adalah untuk membantu petani meningkatkan kesejahteraannya. Nilai $\mathrm{R}^{2}$ sebesar 0,462 yang berarti bahwa besarnya pengaruh motivasi terhadap pengetahuan kebutuhan petani sebesar 46,20\% sedangkan sisanya sebesar $53,80 \%$ dipengaruhi oleh faktor lain yang tidak diteliti.

Pengetahuan tentang komunikasi efektif penyuluh THL TBPP di Kabupaten Garut dipengaruhi oleh jumlah pelatihan, jumlah desa binaan dan motivasi. Jumlah pelatihan berpengaruh nyata terhadap pengetahuan komunikasi efektif dengan nilai koefisien regresi $-0,149$. Nilai koefisien regresi negatif karena jumlah pelatihan yang diikuti oleh penyuluh THL TBPP dalam tiga tahun terakhir rata-rata hanya tiga kali (Tabel 12) masuk dalam kategori rendah. Selain dari itu, pelatihan yang diikuti sebagian besar hanya berdasarkan undangan dari Balai Besar Pelatihan Pertanian Pusat yang menyelenggarakan pelatihan teknis bagi THL TBPP dari berbagai daerah sehingga belum didasarkan pada kebutuhan di lapangan. Pengetahuan komunikasi efektif merupakan variabel kompetensi yang bersifat non teknis dalam kegiatan 
bidang pertanian sehingga untuk meningkatkannya diperlukan pelatihan non teknis bagi penyuluh THL TBPP. Jumlah desa binaan berpengaruh nyata terhadap pengetahuan komunikasi efektif dengan nilai koefisien regresi $-1,653$. Semakin banyak jumlah desa binaan maka semakin banyak waktu tersita di perjalanan sehingga THL TBPP tidak memiliki waktu yang cukup memadai untuk meningkatkan pengetahuannya tentang materi penyuluhan yang mudah dipahami petani. Selain itu waktu untuk berkomunikasi menyampaikan materi penyuluhan kepada kelompok tani juga menjadi terbatas. Hal ini menyebabkan pemahaman THL TBPP tentang komunikasi efektif menjadi rendah. Motivasi berpengaruh sangat nyata terhadap pengetahuan komunikasi efektif dengan nilai keofisien regresi 0,390 . Hal ini bermakna bahwa semakin besar motivasi maka pengetahuan tentang komunikasi yang efektif akan semakin meningkat. Motivasi THL TBPP untuk berprestasi, berafiliasi dan motivasi atas pekerjaannya memberikan dorongan yang besar untuk meningkatkan pengetahuan tentang komunikasi efektif sehingga THL TBPP berupaya agar pesan/materi penyuluhan yang disampaikan kepada petani mudah dipahami. Persamaan regresi untuk variabel kompetensi pengetahuan penyuluh THL TBPP terhadap komunikasi efektif dapat dituliskan sebagai berikut:

$\mathrm{Y}_{._{4}}=-0,989-0,149 \mathrm{X} 1_{._{3}}-1,653 \mathrm{X} 1_{{ }_{4}}+0,390 \mathrm{X} 2$

Keterangan : $\quad \mathrm{Y}_{._{4}}=$ Pemahaman komunikasi efektif $\mathrm{X} 1 ._{3}=$ Jumlah pelatihan

$\mathrm{X} 1_{4}=$ Jumlah desa binaan

$\mathrm{X} 2$ = Motivasi

Berdasarkan persamaan tersebut dapat disampaikan bahwa untuk meningkatkan pengetahuan THL TBPP terhadap komunikasi efektif dapat dilakukan dengan menambah jumlah pelatihan (teknis dan non teknis), mengurangi jumlah desa binaan dengan menambah jumlah penyuluh pertanian dan meningkatkan motivasi untuk berprestasi, berafiliasi dan meningkatkan jumlah honor. Nilai $\mathrm{R}^{2}$ sebesar 0,627 yang berarti bahwa besarnya pengaruh jumlah pelatihan, jumlah desa binaan dan motivasi terhadap pengetahuan komunikasi efektif sebesar $62,70 \%$ sedangkan sisanya sebesar 37,30\% dipengaruhi oleh faktor lain yang tidak diteliti

Secara keseluruhan, faktor-faktor yang diduga mempengaruhi kompetensi penyuluh THL TBPP yaitu karakteristik individu (umur, pendidikan formal, jumlah pelatihan, jumlah desa binaan dan jumlah kelompok tani binaan), motivasi kerja dan persepsi. Berdasarkan Tabel 6 dilihat bahwa faktor jumlah kelompok tani dan motivasi berpengaruh sangat nyata terhadap kompetensi. Hal ini bermakna bahwa kedua faktor ini merupakan faktor penting yang berperan terhadap peningkatan kompetensi, atau dengan kata lain tinggi rendahnya tingkat kompetensi penyuluh THL TBPP dipengaruhi seberapa besar pengaruh faktor-faktor tersebut. Faktor jumlah desa berpengaruh nyata terhadap kompetensi namun dengan nilai koefisien negatif, artinya jumlah desa berbanding terbalik dengan tingkat kompetensi. Faktor umur, pendidikan, pelatihan dan persepsi ternyata tidak berpengaruh nyata terhadap kompetensi. Hal ini berarti keempat faktor tersebut kurang berperan dalam peningkatan kompetensi penyuluh THL TBPP. Umur dan persepsi penyuluh THL TBPP cenderung homogen dengan persentase jumlah yang hampir sama, tingkat pendidikan formal rata-rata masih rendah (DIII) dengan latar belakang penyuluhan sangat sedikit. Jumlah pelatihan yang diikuti sangat terbatas karena keterbatasan anggaran sehingga kompetensinya masih rendah. Rata-rata penyuluh THL TBPP hanya mengikuti pelatihan sebanyak tiga kali dalam tiga tahun terakhir yakni pelatihan budidaya tanaman cabai, pelatihan penanganan limbah ternak dan pelatihan agribisnis tanaman jagung.

Faktor motivasi berpengaruh sangat nyata terhadap kompetensi penyuluh THL TBPP dengan nilai koefisien regresi 0,795 . Hal ini bermakna bahwa motivasi sangat berperan dalam meningkatkan tingkat kompetensi. Semakin besar motivasi maka akan semakin tinggi tingkat kompetensinya. Hal ini sesuai dengan hasil penelitian Nuryanto (2008) dan Ma'ruf et al., (2010) yang menemukan bahwa pengaruh motivasi terhadap peningkatan kompetensi sangat signifikan. Apabila motivasi ditingkatkan maka kompetensinya akan meningkat. Tingginya tingkat motivasi akan mengakibatkan tingginya tingkat kompetensi penyuluh THL TBPP. Hasil analisis menunjukkan bahwa rataan nilai motivasi berada pada kategori tinggi dengan nilai 47,14. Tingginya dukungan motivasi ditunjukkan dengan tingginya kebutuhan untuk berprestasi dan sangat tingginya kebutuhan untuk berafiliasi. Namun demikian dukungan motivasi masih dapat ditingkatkan karena dukungan motivasi dari indikator kebutuhan 
akan pekerjaan masih tergolong rendah (Tabel 2).

Faktor jumlah kelompok tani berpengaruh sangat nyata terhadap kompetensi penyuluh THL TBPP dengan nilai koefisien regresi 0,254. Jumlah kelompok tani binaan berperan meningkatkan kompetensi penyuluh THL TBPP. Hal ini berbeda dengan hasil penelitian Sapar et al., (2011) yang menemukan bahwa jumlah kelompok tani binaan tidak berpengaruh nyata terhadap kompetensi penyuluh. Rata-rata jumlah kelompok tani yang dibina penyuluh THL TBPP sebanyak 10 kelompok yang masuk dalam kategori sedang. Banyaknya jumlah kelompok tani binaan akan menyebabkan penyuluh THL TBPP lebih banyak belajar dan mencari informasi tentang materi penyuluhan yang akan disampaikan dan upaya pemecahan masalah yang dihadapi kelompok tani sehingga akan menambah pengetahuan dan keterampilannya. Semakin banyak kelompok tani binaan maka tingkat kompetensinya akan semakin meningkat. Namun demikian, Departemen Pertanian telah menyatakan bahwa idealnya seorang penyuluh hanya membina 6-8 kelompok tani (Hernanda, 2015). Kegiatan penyuluhan hanya akan berjalan dengan efektif jika seorang penyuluh pertanian memiliki jumlah kelompok tani binaan tidak lebih dari delapan kelompok tani (Sapar, 2011). Penyuluh pertanian yang memiliki jumlah kelompok tani binaan terlalu banyak tidak akan memiliki waktu yang cukup memadai untuk menambah dan memperdalam pengetahuan dan keterampilannya dalam rangka menjaga kualitas kegiatan penyuluhannya sehingga kurangnya waktu dan tingginya beban kerja akan menjadi hambatan bagi seorang penyuluh pertanian untuk meningkatkan kompetensinya (Lakai et al., 2012). Kondisi ini dapat diatasi dengan penambahan jumlah penyuluh pertanian untuk mengurangi beban jumlah kelompok tani binaan yang terlalu banyak. Dengan penambahan jumlah penyuluh pertanian maka beban jumlah kelompok tani akan terbagi kepada penyuluh pertanian yang baru sehingga beban setiap penyuluh THL TBPP akan semakin berkurang. Dengan demikian akan tersedia waktu yang cukup memadai bagi penyuluh THL TBPP untuk menambah dan memperdalam pengetahuan dan keterampilan untuk meningkatkan kompetensinya.

Faktor jumlah desa berpengaruh nyata terhadap kompetensi penyuluh THL TBPP namun dengan nilai koefisien regresi negatif yakni -1,685. Hal ini bermakna semakin banyak jumlah desa maka tingkat kompetensi akan semakin rendah. Kondisi ini berbeda dengan hasil penelitian Sapar et al., (2011) yang menemukan bahwa jumlah desa/luas wilayah binaan tidak berpengaruh nyata terhadap kompetensi penyuluh. Hasil analisis menunjukkan bahwa rataan jumlah desa binaan 2 yang masuk kategori sedang. Banyaknya jumlah desa binaan menjadi kendala bagi penyuluh THL TBPP menyebabkan banyaknya waktu tersita di perjalanan sehingga waktu bagi penyuluh THL TBPP untuk menambah pengetahuan dan ketrampilannya guna mempersiapkan materi penyuluhan menjadi sangat terbatas. Pemerintah Provinsi Jawa Barat telah berupaya untuk mengatasi permasalahan ini dengan cara memberikan bantuan uang muka senilai Rp4.000.000,00 untuk pembelian kendaraan bermotor supaya seluruh penyuluh THL TBPP memiliki sepeda motor untuk menunjang aktivitasnya. Namun sepertinya upaya tersebut belum cukup berhasil sehingga perlu dilakukan upaya mengurangi jumlah desa binaan setiap penyuluh THL TBPP dengan cara menambah jumlah penyuluh pertanian. Dengan demikian beban jumlah desa binaan akan berkurang karena terbagi kepada penyuluh pertanian yang baru sehingga penyuluh THL TBPP akan memiliki waktu yang memadai untuk menambah pengetahuan dan ketrampilannya supaya kompetensinya meningkat.

Berdasarkan nilai koefisien regresi pada Tabel 5, dapat dituliskan model regresi sebagai berikut:

$$
\mathrm{Y}=-0,377-1,685 \mathrm{X} 1_{._{4}}+0,254 \mathrm{X} 1_{._{5}}+0,795 \mathrm{X} 2
$$

Keterangan: $\mathrm{Y} 1=$ Kompetensi

$\mathrm{X} 1_{4}=$ Jumlah desa

$\mathrm{X} 1 .{ }_{5}=$ Jumlah kelompok tani

$\mathrm{X} 2$ = Motivasi

Berdasarkan persamaan tersebut dapat disampaikan bahwa untuk meningkatkan kompetensi penyuluh THL TBPP dapat dilakukan dengan cara menambah jumlah penyuluh pertanian untuk mengurangi jumlah desa binaan dan jumlah kelompok tani binaan, meningkatkan motivasi dengan menambah jumlah honor. Nilai $\mathrm{R}^{2}$ sebesar 0,930 artinya pengaruh faktor-faktor tersebut di atas terhadap kompetensi sebesar 93\%, sedangkan sisanya sebesar 7\% dipengaruhi oleh faktor lain yang tidak diteliti.

\section{Kesimpulan}

Tingkat kompetensi penyuluh THL TBPP 
di Kabupaten Garut rata-rata berada pada kategori rendah, yang berarti belum memiliki kompetensi yang diperlukan sebagai penyuluh pertanian. Rendahnya tingkat kompetensi disebabkan tugasnya yang cukup banyak namun fasilitas yang disediakan oleh pemerintah dalam mendukung pelaksanaan kegiatan penyuluhan pertanian sangat terbatas diantaranya kurangnya jumlah pelatihan dan kecilnya honor yang diterima. Hal ini terlihat pada rendahnya tiga variabel kompetensi yakni pemahaman potensi wilayah, pemahaman kebutuhan petani, dan pemahaman penyusunan laporan meskipun dua variabel berada pada kategori tinggi yakni pemahaman tentang informasi teknologi dan pemahaman tentang komunikasi yang efektif. Pemahaman terhadap kebutuhan petani dipengaruhi oleh motivasi sedangkan pemahaman tentang komunikasi yang efektif dipengaruhi oleh jumlah pelatihan, jumlah desa binaan dan motivasi kerja.

Secara keseluruhan, kompetensi penyuluh THL TBPP dipengaruhi oleh faktor jumlah kelompok tani binaan, jumlah desa binaan dan motivasi kerja. Untuk meningkatkan kompetensi penyuluh THL TBPP di Kabupaten Garut dapat dilakukan dengan cara menambah jumlah penyuluh pertanian untuk mengurangi jumlah desa binaan dan jumlah kelompok tani binaan, menambah jumlah pelatihan dan menyesuaikan materi pelatihan dengan kebutuhan serta menambah jumlah honor untuk meningkatkan motivasi kerja.

\section{Daftar Pustaka}

Anwas OM, Sumardjo, Asngari PS, Tjitropranoto P. 2010. Model pengembangan kompetensi penyuluh berbasis pemanfaatan media. Jurnal Penyuluhan. 6(1):1-10

Anwas OM. 2011. Kompetensi penyuluh pertanian dalam memberdayakan petani. Jurnal Matematika, Saint dan Teknologi. 12(1):46-55.

BP4K Kabupaten Garut. 2016. Programa Penyuluhan BP4K Kabupaten Garut Tahun 2016.

BPS Jawa Barat. 2015. Jawa Barat dalam Angka 2015. Badan Pusat Statistik Provinsi Jawa Barat.

BPS Kabupaten Garut. 2016. Kabupaten Garut dalam Angka 2016. Badan Pusat Statistik Kabupaten Garut.

Brodeur CW, Higgins C, Gonzalez SG, Craig DD, Haile T. 2011. Designing a competency-based new county extension personnel training program: A Novel Approach. Journal of Extension. 49(3):116.

Cyr LF. 2008. Facilitation Competence: A Catalyst for Effective Extension Work. Journal of Extension. 46(4):18-23.

Firmansyah, Amanah S, Sadono D. 2015. Motivasi, kepuasan kerja dan kinerja penyuluh kehutanan di Kabupaten Cianjur Jawa Barat. Jurnal Penyuluhan, 11(1): 11-22.

Hernanda TAP. 2015. Kinerja penyuluh pertanian di Kabupaten Ogan Komering Ulu (OKU) Selatan Provinsi Sumatera Selatan. [tesis]. Bogor (ID): Program Pascasarjana, Institut Pertanian Bogor.

Hernanda TAP, Fatchiya A, Sarma M. 2015. Tingkat kinerja penyuluh pertanian di Kabupaten Ogan Komering Ulu (OKU) Selatan. Jurnal Penyuluhan. 11(1):79-90.

Hubeis AVS. 2009. Motivasi, kepuasan kerja dan produktivitas penyuluh pertanian lapangan: Kasus Kabupaten Sukabumi. Jurnal Penyuluhan. 3 ( 2):90-99.

Ibrahim JT. 2001. Kajian reorientasi penyuluhan pertanian ke arah pemenuhan kebutuhan petani di Propinsi Jawa Timur. [disertasi]. Bogor (ID): Program Pascasarjana, Institut Pertanian Bogor.

[Kemenkeu] Kementerian Keuangan. 2014. Peraturan Menteri Keuangan No.53 Tahun 2014 Tentang Standar Biaya Masukan Tahun Anggaran 2015. Jakarta (ID): Kemenkeu.

[Kemennakertrans] Kementerian Tenaga Kerja dan Transmigrasi. 2013. Peraturan Menteri Tenaga Kerja dan Transmigrasi No 43 Tahun 2013 tentang Penetapan Rancangan Standar Kompetensi Kerja Nasional Indonesia Kategori Pertanian Golongan Pokok Jasa Pelayanan Teknis Golongan Penyuluhan Sub Golongan Penyuluhan Pertanian Menjadi Standar Kompetensi Kerja Nasional Indonesia. Jakarta (ID): Kemennakertrans.

[Kementan] Kementerian Pertanian. 2011. Peraturan Menteri Pertanian No.03 Tahun 2011 Tentang Pedoman Pembinaan Tenaga Harian Lepas Tenaga Bantu Penyuluh Pertanian. Jakarta (ID): Kementan.

[Kementan] Kementerian Pertanian. 2015. Peraturan Menteri Pertanian No. 14 Tahun 2015 Tentang Pedoman Pengawalan dan Pendampingan Terpadu Penyuluh, Mahasiswa, dan Bintara Pembina Desa dalam Rangka Upaya Khusus Peningkatan 
Produksi Padi, Jagung dan Kedelai. Jakarta (ID): Kementan.

Lakai D, Jayaratne KSU, Moore GE, Kistler MJ. 2012. Barriers and effective educational strategies to develop extension agents' professional competencies. Journal of Extension. 50(40):1-7

Lewis RB. 1972. Motivation model for extention. Journal of Extension. 10(4):23-34

Lindner JR. 1998. Understanding employe motivation. Journal of Extension. 36(3): 26-30

Mardikanto T. 1993. Penyuluhan Pembangunan Pertanian. Sebelas Maret University. Press. Surakarta

Mardikanto T. 2009. Sistem Penyuluhan Pertanian. Surakarta: LPP UNS dan UNS Press.

Ma'ruf NA, Siswanto. 2010. Pengaruh motivasi terhadap peningkatan kompetensi bidan desa di Kabupaten Malang. Jurnal Sistem Kesehatan. 13(1):77-82.

Ningrum W, Sunuharyo BW, Hakam MS. 2013. Pengaruh pendidikan dan pelatihan terhadap kinerja karyawan (studi pada karyawan joint operating body pertamina-PetroChina Jawa Timur). Malang (ID): Jurnal Administrasi Bisnis (JAB). 6(2): 1-8.

Nuryanto BG. 2008. Kompetensi penyuluh dalam pembangunan pertanian di Provinsi Jawa Barat. [disertasi]. Bogor (ID): Program Pascasarjana, Institut Pertanian Bogor.

Paay P. 2012. Strategi peningkatan kinerja tenaga harian lepas tenaga bantu penyuluh pertanian di Kabupaten Merauke. [tesis]. Makassar (ID): Program Pascasarjana, Universitas Hasanuddin Makassar.

[Pusluhtan] Pusat Penyuluhan Pertanian. 2016. Sistem Manajemen Informasi Pertanian. BPPSDMP Kementerian Pertanian. [internet]. [diacu 2016 Januari 18]. Tersedia pada: https://app2.pertanian. go.id/simluh.

Putri IW, Fatchiya A, Amanah S. 2016. Pengaruh pelatihan non teknis terhadap kinerja penyuluh pertanian BP4K di Kabupaten Bungo Provinsi Jambi. Jurnal Penyuluhan. 12(1):43-50.

Robbins SP. 1996. Perilaku Organisasi edisi Bahasa Indonesia, Jilid 1. Jakarta: Prenhallindo.

Sapar. 2011. Faktor - faktor yang mempengaruhi kinerja penyuluh pertanian dan dampaknya pada kompetensi petani kakao di empat wilayah Sulawesi Selatan. [disertasi]. Bogor (ID): Program
Pascasarjana, Institut Pertanian Bogor.

Sapar, Jahi A, Asngari PS, Saleh A, Purnaba IGP. 2011. Faktor - faktor yang berpengaruh pada kinerja penyuluh pertanian dan dampaknya pada kompetensi petani kakao di empat wilayah Sulawesi Selatan. Jurnal Forum Pascasarjana. 34(4):297-305.

Suhanda NS, Jahi A, Sugihen BG, Susanto D. 2008. Kinerja penyuluh pertanian di Jawa Barat. Jurnal Penyuluhan. 4(2):100-108.

Sumardjo. 2010. Penyuluhan menuju pengembangan kapital manusia dan kapital sosial dalam mewujudkan kesejahteraan rakyat. Orasi Ilmiah Guru Besar dalam Rangka Dies Natalis IPB ke47. Bogor: Institut Pertanian Bogor.

Van den Ban AW, Hawkins HS. 1999. Penyuluhan Pertanian. Yogyakarta: Penerbit Kanisius.

Wuriani, Zakso A, Suib M. 2014. Kontribusi karakteristik individu dan komitmen profesional terhadap kepuasan kerja dosen prodi keperawatan. Jurnal Pendidikan dan Pembelajaran. 3(8):1-15. 